\title{
STRATEGIC RESEARCH PROGRAMS IN THE AREA OF TECHNICAL INNOVATIONS - CASE STUDY ANALYSES
}

\author{
Ludmiła WALASZCZYK \\ The Institute for Sustainable Technologies - National Research Institute in Radom, Poland \\ e-mail: ludmila.walaszczyk@itee.radom.pl
}

\begin{abstract}
The development of the knowledge-based economy requires undertaking many actions aimed at increasing competitiveness of enterprises. These actions include, among others, the execution of strategic research programs, which are characterized by a great number of levels, a multitude of objectives and results, and high budgets. In order for the program to be managed correctly, it is necessary to have a complex and effective evaluation system dedicated to such types of programs. The article presents a global case study analysis of the evaluation of strategic research programs. The author examines the evaluation criteria and methods used in the evaluation processes at different structural levels of the programs and different times. After getting the results from the analysis, then the author indicates the gaps, which appeared during the evaluation process, and indicates what steps should be taken in order to improve the evaluation process of a strategic research program.
\end{abstract}

Keywords: strategic research program, evaluation criteria, evaluation methods, structural level, strategic management.

\section{Introduction}

Dynamic changes in the economy coming from, among others, the market globalization and the increase in the dynamics of innovation processes contribute to the development of the strategic management process in the organization (Murawska, 2008).

The main aim of strategic management (Andrews, 1980; Barabba, Ackoff, 2002; Drucker, 2002; Gierszewska, 2000; Gołębiewski, 2001; Krupski, 1999; Porter, 1980; Romanowska, Wachowiak, 2006) is to plan the organizational activities in a long-term perspective, considering the development of the organization in the future, and not to think only about the current or past position (Obój, 1998). In order to achieve strategic objectives, it is necessary to build an appropriate organizational base (Obój, 1998), including not only material resources (e.g., financial, staff, technical), but non-material resources as well (i.e., systems for knowledge management) (Łopacińska, Wnuk, 2014).

One of such systems in the organization is the evaluation system, used most frequently in the area of project management, but it can also be used to evaluate a complex strategy executed by the or- ganization and to support the decision-making process.

The main aim of evaluation in strategic management is to support management processes in the organization, which enable, among others, the improvement of the existing management structures, procedures, and processes; the minimization of negative management effects directed at the outcomes; the increase in work efficiency through the verification of the fulfillment of the objectives planned and the quality of the results obtained; the improvement in the efficiency of activities through the verification of the topicality of the strategy objectives.

Despite a significant meaning of evaluation in strategic management, there are several factors that hamper its use, among others (Haber, Szałaj, 2010), the lack of complex evaluation systems, the lack of directions concerning the use of the evaluation results; the lack of systematic implementation of recommendations into practice; evaluation considered to be equivalent with control.

Such gaps cause that the evaluation process can be very complicated. The aim of the article is to analyze case studies of strategic research program evaluation. 


\section{Methodological procedure}

Strategic research programs for case study analysis were selected in two phases, that is, (Lopacińska, 2012; Łopacińska, 2013), the first one included the indication of criteria, which were the base for the selection of strategic programs for the analysis, the second one concerned the selection of programs with the consideration of the criterion - access to information on the program evaluation.

The following criteria were indicated:

- subject criteria,

- formal criteria.

The subject criteria concerned the aspects linked to the character of a strategic research program, whereas the formal criteria took into consideration the functions of institutions in the program.

The subject criteria include the following groups of sub-criteria:

- thematic sub-criterion,

- economic criterion,

- geographic criterion.

Factual analysis, considering the thematic criterion, included the identification and analysis of cognitive and practical objectives of strategic research programs.

Cognitive objectives included the following:

- extension of knowledge on the analyzed phenomena,

- generation of new research areas,

- design of methods and models.
Formal analysis included the verification of the following aspects:

- timeframe of the program,

- institution coordinating the program,

- institution financing the program,

- institutions entitled to get the funds for the program,

- budget of the program,

- science discipline.

The consideration of the aforementioned criteria enabled the author to select 12 strategic research programmes.

\section{Case study analysis}

The author analyzed the examples of strategic research programs at different structural levels (research projects, thematic groups, strategic program as a whole) and in different timeframes (ex-ante, ongoing, mid-term, ex-post).

The selected criteria were met by the following strategic research programs (Table 1, Table 2): Core Research for Evolutional Science and Technology (CREST), Advanced Technology Program (ATP), Exploratory Research for Advanced Technology (ERATO), h2 Early Adopters (h2EA), Hydraulic Turbine Research Program, Finnish Nanoscience and Nanotechnology (FinNano), Premium Automotive Research and Development (PARD), Competence Centre Program, PINTA - Clean Surfaces, Voucher for Innovations, and Program for Interdisciplinary Materials Research Consortia.

Table 1. Strategic research programs included in the analysis

(source: own study)

\begin{tabular}{|c|c|c|c|}
\hline $\begin{array}{l}\text { Name of the strategic } \\
\text { research program }\end{array}$ & $\begin{array}{l}\text { Subject of the strategic } \\
\text { research program }\end{array}$ & $\begin{array}{l}\text { Coordinating } \\
\text { institution }\end{array}$ & $\begin{array}{l}\text { Evaluation } \\
\text { type }\end{array}$ \\
\hline $\begin{array}{l}\text { Core Research } \\
\text { for Evolutional Science } \\
\text { and Technology } \\
\text { (CREST) }\end{array}$ & $\begin{array}{l}\text { To develop technologies enhancing na- } \\
\text { tional innovation performance. To pro- } \\
\text { mote basic research in strategic areas } \\
\text { important for the national economy. }\end{array}$ & $\begin{array}{l}\text { Japan Science and } \\
\text { Technology Agency } \\
\text { (JST) }\end{array}$ & Ex-ante \\
\hline $\begin{array}{l}\text { Advanced Technology } \\
\text { Program (ATP) }\end{array}$ & $\begin{array}{l}\text { To develop innovative technologies } \\
\text { aimed at the construction of innovative } \\
\text { products, services, and industrial pro- } \\
\text { cesses. }\end{array}$ & $\begin{array}{l}\text { National Institute } \\
\text { of Standards and Tech- } \\
\text { nology (NIST) - United } \\
\text { States }\end{array}$ & Ex-ante \\
\hline
\end{tabular}


Table 1. Strategic research programs included in the analysis (cont.)

(source: own study)

\begin{tabular}{|c|c|c|c|}
\hline $\begin{array}{l}\text { Name of the strategic } \\
\text { research program }\end{array}$ & $\begin{array}{l}\text { Subject of the strategic } \\
\text { research program }\end{array}$ & $\begin{array}{l}\text { Coordinating } \\
\text { institution }\end{array}$ & $\begin{array}{l}\text { Evaluation } \\
\text { type }\end{array}$ \\
\hline $\begin{array}{l}\text { Exploratory Research } \\
\text { for Advanced Technology } \\
\text { (ERATO) }\end{array}$ & $\begin{array}{l}\text { To generate new areas of scientific } \\
\text { research in order to develop innova- } \\
\text { tive products. }\end{array}$ & $\begin{array}{l}\text { Japan Science and } \\
\text { Technology Agency } \\
\text { (JST) }\end{array}$ & $\begin{array}{l}\text { Ex-ante } \\
\text { Ongoing }\end{array}$ \\
\hline $\begin{array}{l}\text { h2 Early Adopters Program } \\
\text { (h2EA) }\end{array}$ & $\begin{array}{l}\text { To adjust hydrogen technologies } \\
\text { to national hydrogen economy } \\
\text { and to increase attractiveness of the } \\
\text { renewable energy sector. }\end{array}$ & Industry Canada & Ongoing \\
\hline $\begin{array}{l}\text { Hydraulic Turbine Research } \\
\text { Program }\end{array}$ & $\begin{array}{l}\text { To initiate cooperation between } \\
\text { industry and science within new } \\
\text { initiatives in the use of water energy } \\
\text { at national and international levels. }\end{array}$ & $\begin{array}{l}\text { Royal Institute of Tech- } \\
\text { nology - Sweden }\end{array}$ & Ongoing \\
\hline $\begin{array}{l}\text { Finnish Nanoscience } \\
\text { and Nanotechnology } \\
\text { Program (FinNano) }\end{array}$ & $\begin{array}{l}\text { To develop and to commercialize } \\
\text { technical innovations in nano scale. } \\
\text { To strengthen international coopera- } \\
\text { tion of Finnish scientific organiza- } \\
\text { tions in the nanotechnology area. }\end{array}$ & $\begin{array}{l}\text { Finnish Funding Agen- } \\
\text { cy for Innovation } \\
\text { (TEKES) }\end{array}$ & Mid-term \\
\hline $\begin{array}{l}\text { Premium Automotive } \\
\text { Research and Development } \\
\text { program (PARD) }\end{array}$ & $\begin{array}{l}\text { To increase competitiveness of the } \\
\text { automotive sector through the de- } \\
\text { velopment of new products and } \\
\text { services and to form new skills } \\
\text { and qualifications of staff in the } \\
\text { automotive sector. }\end{array}$ & $\begin{array}{l}\text { Warwick Manufactur- } \\
\text { ing Group (WMG) - } \\
\text { United Kingdom }\end{array}$ & Mid-term \\
\hline Competence Centre Program & $\begin{array}{l}\text { To increase competitiveness of the } \\
\text { national innovation system through } \\
\text { the development of new technologi- } \\
\text { cal products and to promote the } \\
\text { cooperation between industry and } \\
\text { science. }\end{array}$ & $\begin{array}{l}\text { ELIKO Technology } \\
\text { Competence Centre in } \\
\text { Electronics, Infor- } \\
\text { mation and Communi- } \\
\text { cation Technologies - } \\
\text { Estonia }\end{array}$ & Mid-term \\
\hline PINTA - Clean Surfaces & $\begin{array}{l}\text { To do research and expertise within } \\
\text { the use of material technologies for } \\
\text { the development of innovative and } \\
\text { competitive products. }\end{array}$ & $\begin{array}{l}\text { Finnish Funding Agen- } \\
\text { cy for Innovation } \\
\text { (TEKES) }\end{array}$ & Ex-post \\
\hline Voucher for Innovations & $\begin{array}{l}\text { To support SMEs within services } \\
\text { and implementation or development } \\
\text { of innovations. }\end{array}$ & $\begin{array}{l}\text { Polish Agency for En- } \\
\text { terprise Development } \\
\text { (PARP) }\end{array}$ & Ex-post \\
\hline $\begin{array}{l}\text { Program for Interdisciplinary } \\
\text { Materials Research Consortia }\end{array}$ & $\begin{array}{l}\text { To do interdisciplinary research in } \\
\text { the area of material engineering. }\end{array}$ & $\begin{array}{l}\text { Swedish Foundation for } \\
\text { Strategic Research }\end{array}$ & Ex-post \\
\hline
\end{tabular}


Table 2. Structural levels of the evaluation process (source: own study)

\begin{tabular}{|l|c|c|c|}
\hline \multirow{2}{*}{ Strategic research program } & \multicolumn{2}{c|}{ Structural level } \\
\cline { 2 - 4 } & Project level & $\begin{array}{c}\text { Thematic } \\
\text { group level }\end{array}$ & $\begin{array}{c}\text { Strategic } \\
\text { program level }\end{array}$ \\
\hline $\begin{array}{l}\text { Core Research for Evolutional Science } \\
\text { and Technology (CREST) }\end{array}$ & $\mathrm{X}$ & $\mathrm{X}$ & \\
\hline Advanced Technology Program (ATP) & $\mathrm{X}$ & $\mathrm{X}$ \\
\hline $\begin{array}{l}\text { Exploratory Research for Advanced Technology } \\
\text { Program (ERATO) }\end{array}$ & $\mathrm{X}$ & $\mathrm{X}$ \\
\hline h2 Early Adopters Program (h2EA) & $\mathrm{X}$ & $\mathrm{X}$ \\
\hline Hydraulic Turbine Research Program & & & $\mathrm{X}$ \\
\hline $\begin{array}{l}\text { Finnish Nanoscience and Nanotechnology Program } \\
\text { (FinNano) }\end{array}$ & & & $\mathrm{X}$ \\
\hline $\begin{array}{l}\text { Premium Automotive Research and Development } \\
\text { (PARD) }\end{array}$ & $\mathrm{X}$ & $\mathrm{X}$ & $\mathrm{X}$ \\
\hline Competence Centre Program & & & $\mathrm{X}$ \\
\hline PINTA - Clean surfaces (PINTA) & & & \\
\hline Voucher for Innovations & & & \\
\hline $\begin{array}{l}\text { Program for Interdisciplinary Materials Research } \\
\text { Consortia }\end{array}$ & & & \\
\hline
\end{tabular}

The author examined the evaluation criteria and the evaluation methods, which were used during the evaluation process of the listed strategic programs.

\section{Ex-ante evaluation}

Case study analysis, which concerned the ex-ante stage, was performed for three strategic research programs: Core Research for Evolutional Science and Technology (CREST), Advanced Technology Program (ATP) and Exploratory Research for Advanced Technology (ERATO).

From the case study analysis, the author conducted that the following criteria were applied in the listed programs: relevance of the subject matter to the directions of national documents; appropriateness of the subject to the beneficiary needs; financial efficiency of a program; effectiveness (mainly scientific experience of staff in the execution of strategic research programs), and complementarily of research projects undertaken within a strategic research program (Table 3).
In the ex-ante evaluation of the CREST program, the standard criteria commonly used in the evaluation of monothematic projects, like relevance, appropriateness, effectiveness, financial efficiency, utility, impact are taken into account. The criterion of sustainability is not considered. Moreover, the assessment of the commercial potential and other important aspects significant for the implementation of products into economy is not performed. On the other hand, an interesting element of the evaluation is the necessity for the approval of the scientific plan by the core expert, even if the evaluation of the projects is successful (criterion - effectiveness).

In the ex-ante evaluation of the American ATP, the evaluation concerned not only the formal aspects as effectiveness, relevance, and financial efficiency, but also market aspects. The market evaluation was performed using desk research method and direct interviews. 
Table 3. Criteria and methods commonly applied in ex-ante evaluation*

(source: own study)

\begin{tabular}{|c|c|c|c|}
\hline & \multicolumn{3}{|c|}{ Name of the strategic research program } \\
\hline & $\begin{array}{c}\text { Core Research } \\
\text { for Evolutional Science } \\
\text { and Technology } \\
(\text { CREST) }\end{array}$ & $\begin{array}{l}\text { Advanced Technology } \\
\text { Program (ATP) }\end{array}$ & $\begin{array}{c}\text { Exploratory Research } \\
\text { for Advanced Technology } \\
\text { (ERATO) }\end{array}$ \\
\hline \multicolumn{4}{|l|}{ Evaluation criteria } \\
\hline Relevance & $\mathrm{X}$ & $\mathrm{X}$ & $\mathrm{X}$ \\
\hline Appropriateness & $\mathrm{X}$ & $\mathrm{X}$ & $\mathrm{X}$ \\
\hline Effectiveness & $\mathrm{X}$ & $\mathrm{X}$ & $\mathrm{X}$ \\
\hline Financial efficiency & $\mathrm{X}$ & $\mathrm{X}$ & $\mathrm{X}$ \\
\hline Utility & $\mathrm{X}$ & & \\
\hline Sustainability & & $\mathrm{X}$ & \\
\hline Impact & $\mathrm{X}$ & & \\
\hline Complementarity & $\mathrm{X}$ & & $\mathrm{X}$ \\
\hline \multicolumn{4}{|l|}{ Evaluation methods } \\
\hline Desk research & $\mathrm{X}$ & $\mathrm{X}$ & $\mathrm{X}$ \\
\hline Direct interviews & $\mathrm{X}$ & $\mathrm{X}$ & \\
\hline Expert panels & & $\mathrm{X}$ & $\mathrm{X}$ \\
\hline Questionnaires & & & $\mathrm{X}$ \\
\hline Direct observations & & $\mathrm{X}$ & \\
\hline
\end{tabular}

A very deep assessment of the products enabled to take a decision on a proper division of funds on innovative technical products, as the aim of the projects executed within the ATP was the development of new technologies and the possibility of the use of the products in a long-term perspective.

Having analyzed the Japanese ERATO program, the author stated that the main elements that were evaluated included the experience of potential managers of research projects and their position in an academic environment. The evaluation of the project proposals was done after the selection of the project managers. From the date, it can be stated that the Japan Science and Technology Agency JST evaluates, among others, skills of the researchers, and usually states that their strong position in the scientific area is equivalent with the success of their research projects.
As it was presented in Table 1, the criterion of sustainability was considered only in the American ATP programme. Probably, it stemmed from the fact that this criterion was characteristic for an ex-post evaluation. In the literature concerning evaluation, sustainability at the ex-ante stage is not frequently considered; however, it seems important mainly due to the necessity for product development, which should be used in a long-term perspective.

The criterion of utility was only considered in the CREST program, in which the financing organization at the ex-ante stage already assumed the necessity for gaining information on the potential use of products planned to be developed.

With regard to the research methods, the following were applied most often: desk research, direct interviews, and expert panel. From the case study analysis, the author stated that financial aspects were evaluated; however, such evaluation was based only 
on expert opinions. Moreover, having analyzed the data, the author concluded that there were no methods used aimed directly at the evaluation of technical products constituting the results of the programs.

\section{Ongoing evaluation}

A case study analysis of the ongoing evaluation was conducted for three strategic research programs: h2 Early Adopters Program (h2EA), Exploratory Research for Advanced Technology Program (ERATO) and Hydraulic Turbine Research Program. The criteria and methods adequate for the ongoing evaluation, and their use in the listed programs is presented in Table 4.

Table 4. Criteria and methods applied in the ongoing evaluation

(source: own study)

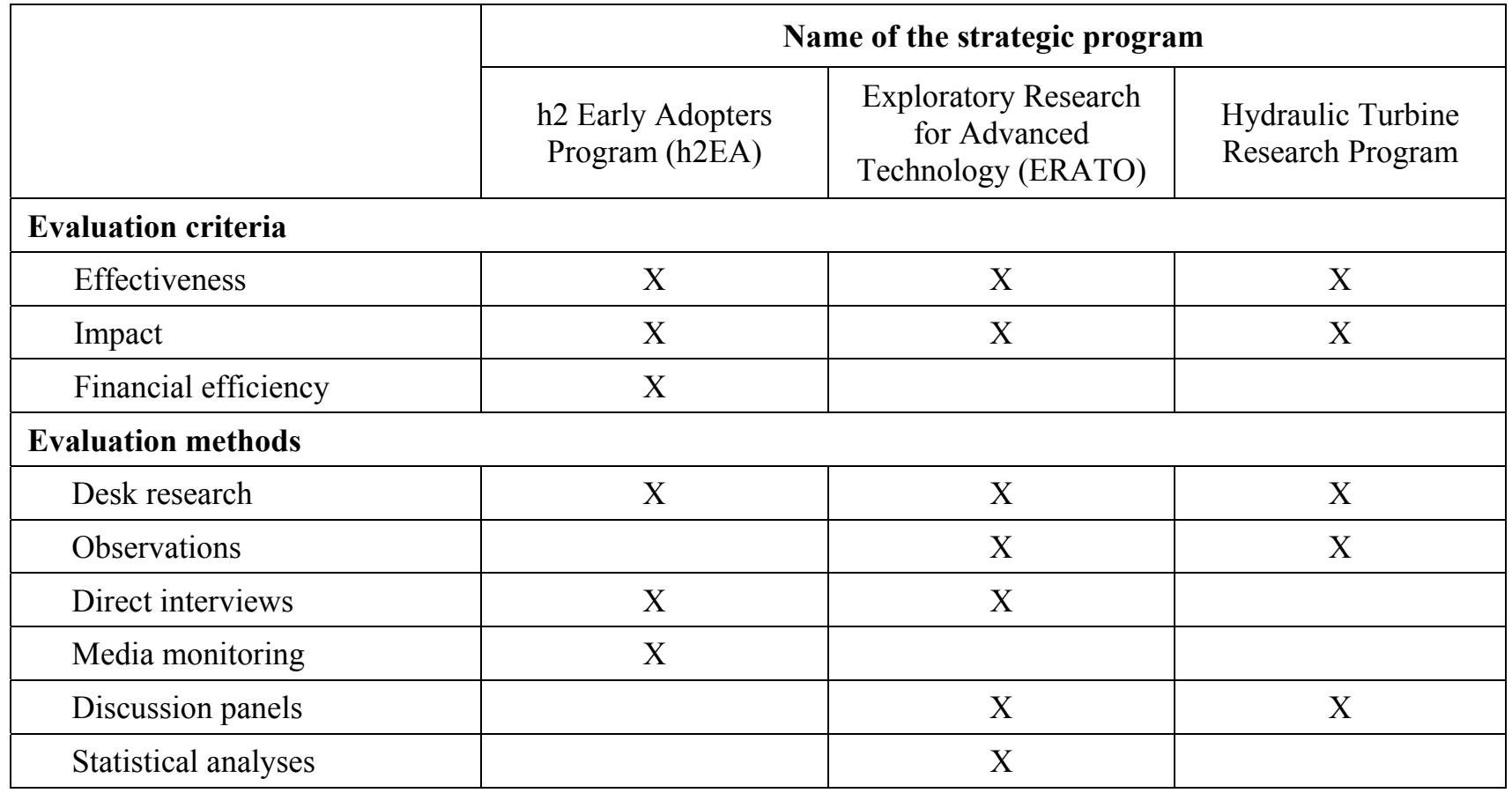

The ongoing evaluation of the h2 Early Adopters Program (h2EA) program was performed systematically, every six months. The most significant criterion was effectiveness (so-called implementation criterion), which included the analysis of key external and internal factors enabling the implementation of program results into economy, and the assessment of the implementation risk, which estimated the probability and the impact of non-planned events on the achievement of the results in the program. The implementation risk assessment aimed at the identification of the most important factors, which could negatively influence the execution of the program. The assessment included: strategic risk (analysis of economic, political, social, and international factors), technological risk (scenario analysis in which national enterprises are not able to introduce new technologies into economy), and the risk at the project level (analysis of production ability of beneficiaries - enterprises, analysis of experience of the research organization in the development of hydrogen technologies, analysis of the style of management in the program).

The research methods included, apart from these commonly used in monothematic research projects, media monitoring aimed at identification and the analysis of information on expectations of beneficiaries within the development of hydrogen technologies, and the possibilities to adjust to their needs.

The evaluation of the ERATO program aimed at the assessment of its effectiveness and impact on the national and international economy. Although the evaluation considered two criteria only, the ERATO program is a good example of how to manage the program efficiently and effectively. Its execution caused the launch of three strategic research pro- 
grams in basic sciences: The International Joint Research Program - IJRP, the Precursory Research for Embryonic Science and Technology - PRESTO, and the Core Research for Evolutional Science and Technology - CREST, all managed by the Japan Science and Technology Agency.

Having analyzed the evaluation of the Hydraulic Turbine Research Program (Sweden), the author noticed that it was partly internal and partly external. The internal experts helped the external experts to understand better the technological issues of the products, which were developed. The evaluation did not only include the organizational assessment of the program, but also a deep content-related assessment of individual research projects. In spite of the fact that one of the features of the evaluation is independence, it is necessary to state that the inclusion of internal experts was very profitable for the correct assessment of the results obtained.

Among the evaluation criteria, effectiveness and impact were most frequent. The effectiveness included a lot of factors enabling to indicate if strategic programs are executed as planned, among others, the level of international cooperation or ways to disseminate the results. In the h2EA program, one of the criteria was the implementation risk of the products; however, the method for its measurement was not proposed.

With regards to financial efficiency, it was only assessed in the Canadian h2 Early Adopters Program (h2EA program). The author did not identify how to measure the efficiency in the program - no specialized method was applied. The measurement of efficiency should be one of the key elements of the ongoing evaluation, as it enables the identification of research projects, which should be continued and these that should be terminated. The analysis indicates that the ongoing evaluation of strategic research programs did not include, among others, the level of the commercial potential of the results planned and the implementation maturity of the results. In the case of the program executed in Canada, the media monitoring was applied, which aimed at searching for specific aspects in scientific articles and the press and processing and analyzing information in order to meet the needs of potential beneficiaries.

\section{Mid-term evaluation}

A case study analysis of the mid-term evaluation was conducted for three strategic research programs: Finnish Nanoscience and Nanotechnology Program (FinNano), Premium Automotive Research and Development program (PARD) and Competence Centre Program.

The mid-term evaluation in the FinNano program was directed at effectiveness of the execution of research projects within the strategic program, their relevance with societal needs, and the impact of the results on the economy. A significant aspect considered during the evaluation was to verify the level of commercialization of the results through making direct online interviews with the project executors. Moreover, the direct interviews with project coordinators were conducted, but the level of satisfaction of beneficiaries was omitted. As a result, the objectives of the FinNano program were executed in a way planned in the project application. Particularly, the international cooperation between research institutes and the possibilities of undertaking similar cooperation in the future were assessed.

In the Premium Automotive Research and Development (PARD) program, the evaluation report included recommendations concerning further execution of the program through the indication, among others, of the necessity of continuous monitoring of progress in the program, the dissemination of information on the program, and the cooperation with enterprises and institutions from the automotive sector. In the evaluation, different research methods were used, for example, an econometric model, which enabled a detailed analysis of the program's impact on the economy. Moreover, the analysis included gross effects of the program (effects that could have been developed even without no financial support of the program) and net effects (effects that are the results of the execution of the program. Net effects were key effects in the evaluation of the effectiveness of a strategic program). The experts also considered the experience gained in the program execution through indicating good and bad practices within the program management.

Having evaluated the Competence Centre Program in Estonia, the author stated that it was executed 
correctly; however, it was not possible to estimate the impact of the program on the economy and scientific environment due to the lack of data only. The efficiency of work and the appropriateness with the needs of beneficiaries needs were evaluated. The basic method used in the evaluation was the interview directed to the representatives of enterprises and the staff participating in the program execution.
The research shows that the mid-term evaluation in analyzed case studies was conducted for strategic research programs as a whole, and not for individual structure levels, for example, research projects.

Case study analysis indicated a great diversity of the use of evaluation criteria and methods (Table 5).

Table 5. Criteria and methods applied in the mid-term evaluation

(source: own study)

\begin{tabular}{|c|c|c|c|}
\hline & \multicolumn{3}{|c|}{ Name of the strategic program } \\
\hline & $\begin{array}{l}\text { Finnish Nanoscience } \\
\text { and Nanotechnology } \\
\text { Program (FinNano) }\end{array}$ & $\begin{array}{c}\text { Premium Automotive } \\
\text { Research } \\
\text { and Development } \\
\text { (PARD) program }\end{array}$ & $\begin{array}{c}\text { Competence Centre } \\
\text { Program }\end{array}$ \\
\hline \multicolumn{4}{|l|}{ Evaluation criteria } \\
\hline Appropriateness & $\mathrm{X}$ & $\mathrm{X}$ & $\mathrm{X}$ \\
\hline Effectiveness & $\mathrm{X}$ & $X$ & $\mathrm{X}$ \\
\hline Complementarity & $\mathrm{X}$ & & $\mathrm{X}$ \\
\hline Impact & $\mathrm{X}$ & $\mathrm{X}$ & $\mathrm{X}$ \\
\hline Financial efficiency & & $\mathrm{X}$ & \\
\hline \multicolumn{4}{|l|}{ Evaluation methods } \\
\hline Desk research & $\mathrm{X}$ & $\mathrm{X}$ & $\mathrm{X}$ \\
\hline Econometric models & & $\mathrm{X}$ & \\
\hline Questionnaires & $\mathrm{X}$ & $\mathrm{X}$ & $\mathrm{X}$ \\
\hline Direct interviews & $\mathrm{X}$ & $\mathrm{X}$ & $\mathrm{X}$ \\
\hline Observations & & & $\mathrm{X}$ \\
\hline Intervention logic & & $\mathrm{X}$ & \\
\hline
\end{tabular}

The criteria most frequently used included: appropriateness, efficiency, and impact. Moreover, other criteria were considered, for example, the complementarity and the commercialization level (FinNano), but in some cases, the financial efficiency was omitted (FinNano, Competence Centre ), which is a significant element of the evaluation in the midterm period of the program's execution. There is, thus, possibility that some programs are not economically efficient.

Due to this fact, it would be desirable to transfer funds to more effective projects or to terminate some non-perspective projects. In the mid-term evaluation, the criteria enabling a detailed evaluation of the results as the implementation maturity or the commer- cial potential were not included. The evaluation included mainly standard methods used in the evaluation of individual monothematic projects, like desk research, direct interviews, but also non-standard approach, for example, econometric model REMIECOTEC. These methods enabled detailed analysis of the programs.

\section{Ex-post evaluation}

A case study analysis of the ex-post evaluation was conducted for three programs: PINTA - Clean Surfaces, Voucher for Innovations, and Program for Interdisciplinary Materials Research Consortia. The criteria and the methods used in the ex-post evaluation are presented in Table 6 . 
Table 6. Criteria and methods used in the ex-post evaluation (source: own study)

\begin{tabular}{|c|c|c|c|}
\hline & \multicolumn{3}{|c|}{ Strategic program } \\
\hline & PINTA - Clean Surfaces & Voucher for Innovations & $\begin{array}{c}\text { Program for Interdiscipli- } \\
\text { nary Materials Research } \\
\text { Consortia }\end{array}$ \\
\hline \multicolumn{4}{|l|}{ Evaluation criteria } \\
\hline Relevance & $\mathrm{X}$ & & \\
\hline Appropriateness & $\mathrm{X}$ & & \\
\hline Effectiveness & $\mathrm{X}$ & $\mathrm{X}$ & $\mathrm{X}$ \\
\hline Financial efficiency & $\mathrm{X}$ & & \\
\hline Impact & $\mathrm{X}$ & $\mathrm{X}$ & $\mathrm{X}$ \\
\hline Utility & & $\mathrm{X}$ & $\mathrm{X}$ \\
\hline Sustainability & & $\mathrm{X}$ & $\mathrm{X}$ \\
\hline Complementarity & $\mathrm{X}$ & & \\
\hline \multicolumn{4}{|l|}{ Evaluation methods } \\
\hline Desk research & & $\mathrm{X}$ & $\mathrm{X}$ \\
\hline \multicolumn{4}{|l|}{ Expert panel } \\
\hline Statistical analysis & & $\mathrm{X}$ & $\mathrm{X}$ \\
\hline Direct interview & $\mathrm{X}$ & $\mathrm{X}$ & $\mathrm{X}$ \\
\hline Discussion panel & $\mathrm{X}$ & & \\
\hline SWOT analysis & $\mathrm{X}$ & & \\
\hline Questionnaires & $\mathrm{X}$ & & \\
\hline
\end{tabular}

The ex-post evaluation of the PINTA - Clean Surfaces program showed that it responded to the needs of SMEs in the area of surface engineering; however, a high scientific level of the results (specialized vocabulary, complicated theoretical models) made their perception difficult, and hampered their transfer into the economy.

In the evaluation, a significance of scientific and technological results of the program, which are innovative and important for further technological development of a country, was underlined. The institutions taking part in the program cooperated with numerous Finnish and international research organizations. Additional effects of the program included scientific publications, presentations, and bachelor, master, and doctoral theses and patents.

The PINTA - Clean Surfaces program had a positive impact on the development of the Finnish science and industry. Research teams applied knowledgedriven approach in their work. It was underlined that a high level of research at the international level motivates the European and global research organizations to execute programs on a similar topic.

The evaluation results of the Voucher for Innovations program showed that almost $70 \%$ of the planned projects were executed. The reasons for not executing projects within the program included, among others, the negative evaluation of the project application, the resignation of the applicant, and the cancelation of the contract with the Polish Agency for Entrepreneurship Development (PARP).The areas, which were represented by the applicants, included industry, scientific, and technical activity; trade and repairs; information and communication; construction; education; health and social care as well as financial and assurance activity. The projects contributed to, among others, the design and the implementation of advanced products and technologies, the development of innovative solutions within 
the areas of company management, and market, financial, or economic analysis.

The ex-post evaluation of the program indicated that the greatest barriers in the program execution included the difficulties in cooperation with research institutions, short-term of the project execution, bureaucracy, the delays in payments from PARP, and incompetency of employees. Having analyzed the impact of the program on entrepreneurs, the author stated that the program helped in increasing the quality of products and competitiveness and market position of companies and improving company management. Based on the analyzed evaluations, it was stated that during the execution of the Voucher for Innovations program, the market situation and the competitiveness of companies - beneficiaries improved. The quality of their products and services was made better as well.

The evaluation of the Program for Interdisciplinary Materials Research Consortia aimed at the analysis of the impact of the developed products on the national economy. Through the use of many research methods, it was stated that the program initiated the modernization process of material sciences in Sweden and stimulated research in this area conducted both by academia and companies. The evaluation did not consider the measurement of the commercial potential of individual products and the impact of the program on the national environment.

The most common standard evaluation criteria at the ex-post stage included effectiveness, financial efficiency, impact, utility, and sustainability. Moreover, such criteria as complementarity, relevance, and the commercialization level of the results were used.

The commercialization aspect was identified only in the case of the PINTA - Clean Surfaces program. In the remaining programs, the commercialization level was not assessed.

With regard to the methods, only these were identified, which are used for the assessment of monothematic projects, among others, desk research, statistical analysis, and interviews. The analysis of financial efficiency was not applied in order to measure the expenditure with relation to the ef- fects achieved. Moreover, the benchmarking method was not used in order to use the results of the programs executed with the positive result and to compare the results with the current program. Moreover, the method aimed at the assessment of technological level of innovation products was not applied.

\section{Conclusions}

The aim of the case study analysis was to present the research results concerning the evaluation criteria and methods used in global strategic research programs at different stages of their execution and their different structural levels (Table 7).

The results of the case study research are the following:

- the efficiency of financial analysis was used too seldom in the strategic research programs that were analyzed,

- the assessment of the technological and legal aspects of innovative products was not performed,

- the commercialization level of the results was assessed only in some cases,

- the market assessment was identified only once (the ATP program) and only at the ex-ante stage,

- with regards to the evaluation methods the author identified the methods used in the assessment of monothematic projects as desk research, expert panel, and direct interviews.

The case study analysis shows that there is no evaluation system that includes all elements to be assessed during the strategic research program execution.

It is very important, as such a system would support the decision making directed at the improvement of the effectiveness and the efficiency of the tasks undertaken within strategic research programs.

The advantage of such a system would be to make simulations on the selection of the research projects, which are the most perspective, from the factual and financial points of view, and which bring scientific and application effects. 
Table 7. Evaluation criteria and methods identified in the case study research (source: own study)

\begin{tabular}{|c|c|c|c|c|}
\hline Evaluation type & Ex-ante & Ongoing & Mid-term & Ex-post \\
\hline \multicolumn{5}{|l|}{ Evaluation criteria } \\
\hline Relevance & $\mathrm{X}$ & $\mathrm{X}$ & & $\mathrm{X}$ \\
\hline Appropriateness & $\mathrm{X}$ & & $\mathrm{X}$ & $\mathrm{X}$ \\
\hline Effectiveness & $\mathrm{X}$ & $\mathrm{X}$ & $\mathrm{X}$ & $\mathrm{X}$ \\
\hline Financial efficiency & $\mathrm{X}$ & $\mathrm{X}$ & $\mathrm{X}$ & $\mathrm{X}$ \\
\hline Utility & $\mathrm{X}$ & & & $\mathrm{X}$ \\
\hline Sustainability & $\mathrm{X}$ & & & $\mathrm{X}$ \\
\hline Impact & $\mathrm{X}$ & $\mathrm{X}$ & $\mathrm{X}$ & $\mathrm{X}$ \\
\hline Complementarity & $\mathrm{X}$ & & $\mathrm{X}$ & $\mathrm{X}$ \\
\hline \multicolumn{5}{|l|}{ Evaluation methods } \\
\hline Desk research & $\mathrm{X}$ & $\mathrm{X}$ & $\mathrm{X}$ & $\mathrm{X}$ \\
\hline Direct interviews & $\mathrm{X}$ & $\mathrm{X}$ & $\mathrm{X}$ & $\mathrm{X}$ \\
\hline Expert panels & $\mathrm{X}$ & $\mathrm{X}$ & & \\
\hline Questionnaires & $\mathrm{X}$ & & $\mathrm{X}$ & $\mathrm{X}$ \\
\hline Statistical analyses & & $\mathrm{X}$ & & $\mathrm{X}$ \\
\hline Financial efficiency analysis & $\mathrm{X}$ & & & \\
\hline Observation & $\mathrm{X}$ & $\mathrm{X}$ & $\mathrm{X}$ & \\
\hline Media monitoring & & $\mathrm{X}$ & & \\
\hline Discussion panels & & $\mathrm{X}$ & & $\mathrm{X}$ \\
\hline Intervention logic & & & $\mathrm{X}$ & \\
\hline Econometric models & & & $\mathrm{X}$ & \\
\hline SWOT analyses & & & & $\mathrm{X}$ \\
\hline
\end{tabular}

The necessity for making simulations comes from the fact that the state-of-the-art indicated that the results obtained in many strategic research programs were not often relevant for the technological and societal needs. The execution of such programs is still continued, although these programs do not bring values or have no perspectives for further development. The most important aspect in such cases is positive formal termination of the program and the launch of a new initiative responding to the scientific and application needs. The executors of such programs are mostly turned toward the final termination of a program, omitting the competitiveness aspect of the national economy. A complex system would contribute to the full assessment of important aspects of a strategic research program and to the execution of such a program in an efficient and effective way.

\section{$5 \quad$ References}

[1] Andrews, K.R., 1980. The Concept of Corporate Strategy. Homewood, Richmond: R.D. Irwin.

[2] Arnold, E., ed., 2008. Mid-term Evaluation of the Competence Centre Programme. Final report, Tallinn.

[3] Avellan, F., Cederwall, K., Hartmann, R., 2002. Hydraulic Turbine Research Programme. Evaluation report, Stockholm.

[4] Barabba, V., Ackoff, R., 2002. The Strategic Management of Intellectual Capital and Organizational Knowledge: A Collection of Readings. Nowy Jork: Oxford University Press.

[5] Drucker, P.H., 2002. Myśli przewodnie Druckera, Warsaw: MT Biznes. 
[6] Gamota, G., ed., 1999. Japan's ERATO and PRESTO Basic Research Programs. [online] Available at: http://www.wtec.org/pdf/erato.pdf [Accessed: 05.04.2016].

[7] Gierszewska, G., 2000. Zarzqdzanie strategiczne. Warsaw: Wydawnictwo Wyższej Szkoły Przedsiębiorczości i Zarządzania.

[8] Gołębiewski, T., 2001. Zarzq̨dzanie strategiczne. Planowanie $i$ kontrola. Warsaw: Wydawnictwo Difin.

[9] Haber, A., Szałaj, M., 2010. Ewaluacja w strategicznym zarzadzaniu publicznym. Warsaw: Polska Agencja Rozwoju Przedsiębiorczości.

[10] Henry, N., Leather J., 2008. PARD - Third Interim Programme Report. Advantage West Midlands.

[11] Independent Administrative Institute Japan Science Technology Agency Office of Basic Research, 2007. Invitation for Application of Research Proposals. Application Guideline. Volume 2. CREST Type Second Term (New Research Areas) PRESTO Type (All Research Areas). [online] Available at: http://www.jst.go.jp /kisoken/boshuu/h19/boshuu/jigyou/en/guideline s/guidelineh19.pdf [Accessed 05.04.2015].

[12] Jakobsen, L., Erdal, T., Knudsen, P.E., Hvidberg M., 2002. Evaluation of the Programme for Interdisciplinary Materials Research Consortia. Case report, Oxford Research.

[13] Koponen, P., Kalander, J.K., Kursisto, M., 2008. FinNano Programme. Intermediate evaluation. Helsinki.

[14] Krupski, R., ed., 1999. Zarzqdzanie strategiczne koncepcje, metody. Wrocław: Wydawnictwo Akademii Ekonomicznej we Wrocławiu.

[15] Łopacińska, L., 2012. Report from the execution of research task No RC/1A/I.4.2/PS Criteria of generating and cognitive and practical objectives of strategic research programmes in the Area of Advanced Technique in the European Union and Worldwide. Not published.

[16] Łopacińska, L., 2013. Report from the execution of research task No RC/3/I.4.2/PS Efficiency and Effectiveness Procedures Applied in Strategic research Programmes in the Area of Advanced Technique in the European Union and Worldwide. Not published.
[17] Łopacińska, L., Wnuk, U., 2014. Analiza indeksu mglistości tekstu w raportach ewaluacyjnych strategicznych programów badawczych w obszarze innowacji technicznych. E-mentor, No 5 (57), pp.43-49.

[18] Murawska, M., 2008. Zarzqdzanie strategiczne niematerialnymi zasobami przedsiębiorstwa. Warsaw: Fundacja Promocji i Akredytacji Kierunków Ekonomicznych.

[19] Obłój, K., 1998. Strategia organizacji. Warsaw: Wydawnictwo PWE.

[20] Penc, J., 1997. Strategie zarzqdzania. Warsaw: Agencja Wydawnicza Placet.

[21] Performance Management Network Inc., 2004. h2 Early Adopters Program (h2EA) - six months progress report. [online] Available at: https://ito.ic.gc.ca/eic/site/ito-oti.nsf/eng/h_0014 8.html [Accessed: 16.05.2016].

[22] Polska Agencja Rozwoju Przedsiębiorczości (Polish Agency for Enterprise Development), 2010. Ocena efektywności i skuteczności programu Bon na innowacje. Final report, Warsaw. [online] Available at: http://poig.parp.gov. pl/files/74/75/77/320/10165.pdf [Accessed: 16.05.2016].

[23] Porter M.E., 1980. Competitive strategy. New York: The Free Press.

[24] Rezendes, L., 1994. Advanced Technology. Proposal Review Process and Treatment of Foreignowned Businesses. [online] Available at: http://archive.gao.gov/t2pbat4/150663.pdf [Accessed: 08.06.2014].

[25] Romanowska, M., Wachowiak, P., 2006. Koncepcje i narzędzia zarzqdzania strategicznego. Warsaw: Oficyna Wydawnicza SGH.

[26] Rossi, P.H., Lipsey, M.W., 2004. Evaluation. A systematic approach. London: Sage publication.

[27] TEKES, 2006. PINTA - Clean Surfaces. 20022006, Technology Programme Report 17/2006, Helsinki. [online] Available at: https://www. tekes.fi/globalassets/julkaisut/pinta_engl_17_06. pdf [Accessed: 16.05.2016]. 